\title{
Heinz 小体に関する研究
}

\section{第 2 編}

家鬼末梢流血中 Heinz 小体と試験管内形成促進法

による核小体との関係について

\author{
指導：国立岩国病院 岩原可副院長 \\ 指導：岡山大学少坂淳夫教授 \\ 国立岩国病院（院長 渡辺真澄博士）
}

松浦貞章

[昭和 34 年 8 月 28 日受稿]

\section{腥音言}

第 1 編に於ては各種疾患々者の流血中に出現した Heinz 小体含有赤血球数 (以下流血中 $\mathrm{H}$ 小体と称す) と吉田・河村氏の試験管内形成促進法䵊法”によつ て形成さ扎た Heinz 小体を含有する赤血球数（以下 促進法 $\mathrm{H}$ 小体と称す）とを湘定して両者を比較検討 し, 流血中H小体と促進法H小体とはその本態を異に するものてあることを明らかにしたか，更に系統的に 流血中 $\mathrm{H}$ 小体と促進法 $\mathrm{H}$ 小体を比較する為に家鬼を用 いて動物実験を行つた. 即ち夫ィ脱血及ひフェニール ヒドラジン，塩酸ヒドロキシラミン注射，四塩化宸 点, 墨计注射等を行い, 流血中 $\mathrm{H}$ 小体及び促進法 $\mathrm{H}$ 小 体を測定して，両者の関係に就て考察した。

\section{実 跧 方 法}

\section{1. 实晚村料}

2 乃至 $3 \mathrm{~kg}$ の成熟家東（倠性家躳は妊娠していな い事を確めて使用）を用い，夫々 5 匹を一群として使 用した.

\section{2. 流血中H小体の測定}

第 1 編と同栚の方法に依つた.

3. 促㸕法H小体の測定

第 1 編と同様の方法に依つた.

\section{4. 促進法に用いる㦈深}

$0.1 \mathrm{~g}$ の塩酸ヒドロキシラミンを生理的食塩水 $100 \mathrm{cc}$ に溶解せしめ, これを原夜として $10^{\circ} \mathrm{C}$ 以下の冷蔵瑓 に保存し, 用に臨みその $0.1 \mathrm{cc}$ を生理的食塩水 $10 \mathrm{cc}$ に稀积し， $1 \mathrm{mg} / \mathrm{dl}$ の浱度として用いた。原液は 2 週 间毎化調整した。
5. 染
色

第 1 編と同樣の方法を用いた。

6. 血液は耳静脈穿刺により得た新鲜血による他， 二重葆酸塩 $2 \mathrm{mg}$ 入りの容器に注射器て耳静脈より 血液 $2 \mathrm{cc} と り ，$ 混和した二重落酸塩加血液を新鮮血 に代用した ${ }^{21}$. 二重畕酸塩 $2 \mathrm{mg}$ に血液 $2 \mathrm{cc}$ を入れ 混和した二重修酸塩加血液について採血直後，1時間 後, 2 時間後, 3 時間後と時間追い促進法 $\mathrm{H}$ 小体を 測定した所, 表 1 の通りの成績を得, 新鮮血の促進法 $\mathrm{H}$ 小体と二重萑酸塩加血液のそれとの平均值に有意の 差は認められず，少くとも 3 時間後迄はこの方法によ つても差支えないことが判つた. 同じ症例から得た赤 血球生理的食塩水浮遊液の促進法 $\mathrm{H}$ 小体平均值媇鮮 血, 二重蓉酸塩加血のそれよりも高く、推計学的に 5

表 1 新鮮血, 二重苳酸加血液, 赤血球生理 食塩水浮遊液の促進法 $\mathrm{H}$ 小体

\begin{tabular}{|c|c|c|c|c|c|}
\hline 採血後の時間 & $(\%)$ & $\begin{array}{c}1 \text { 時間) } \\
\left.(\%)_{0}\right)\end{array}$ & $\begin{array}{l}2 \text { 時間 } \\
\left.(\%)_{0}\right)\end{array}$ & $\begin{array}{l}3 \text { 時間 } \\
(\%)^{2}\end{array}$ & $\begin{array}{l}24 \text { 時間 } \\
(\% \%)^{2}\end{array}$ \\
\hline 新 鮮 血 & $\begin{array}{l}63 \\
57 \\
70 \\
58 \\
65 \\
\end{array}$ & & & & \\
\hline 均 & 62.6 & & & & \\
\hline $\begin{array}{l}\text { 二重偾酸塩 } \\
22 \mathrm{mg} \\
\text { 血液 } 2 \mathrm{cc}\end{array}$ & $\begin{array}{l}75 \\
68 \\
55 \\
48 \\
59 \\
\end{array}$ & $\begin{array}{l}73 \\
71 \\
59 \\
47 \\
52 \\
\end{array}$ & $\begin{array}{l}80 \\
76 \\
52 \\
50 \\
56 \\
\end{array}$ & $\begin{array}{l}79 \\
75 \\
58 \\
60 \\
59 \\
\end{array}$ & $\begin{array}{l}196 \\
203 \\
186 \\
210 \\
176 \\
\end{array}$ \\
\hline 均 & 61.0 & 60.4 & 62.8 & 66.2 & 194.2 \\
\hline $\begin{array}{l}\text { 赤血球生食水 } \\
\text { 浮遊液 }\end{array}$ & $\begin{array}{r}97 \\
101 \\
98 \\
111 \\
82\end{array}$ & & & & $\begin{array}{l}176 \\
185 \\
180 \\
153 \\
162\end{array}$ \\
\hline 均 & 97.2 & & & & 171.0 \\
\hline
\end{tabular}


6996

\%の危険率で有意の羑があつた。これは血情中に溶血 阻止物質が存在するこど', 脱線維素遇程に於ける操 作が或る程度血球に障碍を及ぼす為ではないかと考え られる.24時間冷藏庫に保存した二重㣭酸塩加血液の 促進法 $\mathrm{H}$ 小体と赤血球生理的食塩水浮遊夜のそれとを 比へると前者が有意の盖をもつて多い，長時間保存す る時は二重蓕酸塩によつて赤血球が障碍を受けると考 えられる. 従つて二重苳酸塩加血液で検査する時は出 来得る限り採血直後に行つた.

7. 大量脱血は心臓に直接注射針を穿刺して行つ た.

8. フェニールヒドラジン, 塩酸ヒドロキミラミン は夫々滅菌蒸溜水にて溶解し一定の渡度として, 耳静 脈より注入した.

9. 四塩化炭素は体重毎 $\mathrm{kg} 0.5 \mathrm{cc}$ を筋肉内注射し た.

10. 棢内系填塞は $10 \%$ 墨汁体重每 $\mathrm{kg} 5 \mathrm{cc} ５$ 日間 毎日耳静脈内に注入した。

11. 以上について流血中 $\mathrm{H}$ 小体及び促進法 $\mathrm{H}$ 小体を 可及的每日測定し， 1 週乃至 3 週に及んだ. 参考とし て赤血球及ひ網状赤血球の測定を大部分の症例につい て行つた. 尙以下泩射或は脱血後の日数を数える場合 は注射或は脱血を行つた翌日を以て第 1 日として数え ることとする。

\section{実験成緙並び考按}

\section{1. 健庵家鬼}

健康家农の流血中 $\mathrm{H}$ 小体, 促進法 $\mathrm{H}$ 小体, 赫血球

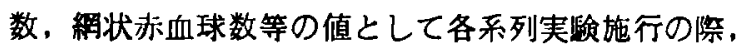
実験施行前に测定したものの平均値を求めて見ると表 2 の通り，流血中H小体は全例にこれを認めず，促進 法 $\mathrm{H}$ 小体は平均 $66.7 \%$, 赤血球数平均 564.4 万, 網状 赤血球数平均 $21.9 \%$ であつた. 安東・田嶋"゙によれは 正常家鬼の赤血球は500万至600万，林らの計数表に

\begin{tabular}{|c|c|c|c|c|}
\hline 検 查 項 & 目 & 例 & 数 & 測定値平均 \\
\hline 流血中 $\mathrm{H}$ 小体 & $(\%)$ & & 60 & 0 \\
\hline 促進法H小体 & $(\%)$ & & 60 & 66.7 \\
\hline 赤 血 球 & （万） & & 55 & 564.4 \\
\hline 棢状赤血球 & $(\% 0)$ & & 55 & 21.9 \\
\hline
\end{tabular}

よれば平均 603 万，554.8万，590万等となつており， 私の値も略々これと一致した成績であつた。私の測定 では網状赤血球の平均値は21.9\%であつたが林らによ れは古 $12.8 \%$ ， $13.2 \%$ ，或は堆雄合せて $9.1 \%$ 等と 報告されている。安東・田嶋“比机ば，春秋17\%。， 夏期 27 乃至 $39 \%$ で，夏期高くなる様であるから，6， $7 ， 8$ 月に行つた $20 匹 と 9 ， 10 ， 11$ 月に行つた $20 匹 に$ ついて表 3 の様な検査項目について平均値の差の検定 を行つた所, 促進法 $\mathrm{H}$ 小体及び赤血球の平均値は推計 学的に有意の差はなく，網状赤血球のみ平均值の差は 有意であつた。しかし網状赤血球数は本研究に於て影

表 3・ 季節による差

\begin{tabular}{|c|c|c|}
\hline 季 節 & 夏月～期 & $\left(\begin{array}{c}z \\
(9 \sim 12 \text { 月 }\end{array}\right)$ \\
\hline 項 目 & 20 & 20 \\
\hline 促進法 $\mathrm{H}$ 小体（\%) & 70.7 & 66.6 \\
\hline 赤 伹 球（万） & 569.6 & 555.5 \\
\hline 網状赤血球 $(\%)$ & 26.1 & 19.0 \\
\hline
\end{tabular}

徱する所が大きくないのでかかる季節による差は無視 して検討を進めることとする。

\section{2. $5 \mathrm{ec} 1$ 回脱血}

$5 \mathrm{cc}$ の脱血を 1 回行い第 4 日迄の経過を見ると赤血 球数. 稀状赤血球数は殆んど影知を受けす，表 4 の通 り，流血中 $\mathrm{H}$ 小体は認めら行す，促進法 $\mathrm{H}$ 小体も健康 家㭸に於けるものと军がなかつた。

表 4

$5 \mathrm{cc}$ 脱血

\begin{tabular}{|c|c|c|c|c|c|c|c|c|c|c|c|c|c|c|c|c|c|c|c|c|}
\hline \multirow{2}{*}{ 病 } & \multicolumn{2}{|c|}{ 第 1 例 } & \multicolumn{2}{|c|}{$\left(\begin{array}{l}q \\
2950 \mathrm{~g}\end{array}\right)$} & \multicolumn{2}{|c|}{ 第 2 例 } & \multicolumn{2}{|c|}{$\left(\begin{array}{l}q \\
2500 \mathrm{~g}\end{array}\right)$} & \multicolumn{2}{|c|}{ 第 3 例 } & \multicolumn{2}{|c|}{$\left(\begin{array}{c}\hat{D} \\
2600 \mathrm{~g}\end{array}\right)$} & \multicolumn{2}{|c|}{ 第 4 例 } & \multicolumn{2}{|c|}{$\left(\begin{array}{c}\delta \\
2350 \mathrm{~g}\end{array}\right.$} & \multicolumn{2}{|c|}{ 第5例 } & \multicolumn{2}{|c|}{$\left(\begin{array}{cc}\hat{t} & \\
2400 \mathrm{~g}\end{array}\right)$} \\
\hline & 流 & 促 & 赤 & 稀 & 流 & 促 & 赤 & 程 & 流 & 促 & 赤 & 程 & 流 & 促 & 赤 & 秱 & 流 & 促 & 赤 & 秝 \\
\hline 前 & 0 & 63 & 578 & 16 & 0 & 57 & 523 & 11 & 0 & 70 & 560 & 18 & 0 & 58 & 621 & 25 & 0 & 65 & 587 & 23 \\
\hline I & 0 & 64 & 563 & 22 & 0 & 50 & 533 & 16 & 0 & 75 & 550 & 15 & 0 & 51 & 590 & 21 & 0 & 58 & 580 & 19 \\
\hline 2 & 0 & 70 & 581 & 23 & 0 & 61 & 546 & 20 & 0 & 72 & 576 & 19 & 0 & 63 & 587 & 24 & 0 & 70 & 603 & 30 \\
\hline 3 & 0 & 83 & 559 & 31 & 0 & 64 & 549 & 22 & 0 & 63 & 539 & 17 & 0 & 73 & 609 & 20 & 0 & 80 & 596 & 18 \\
\hline 4 & 0 & 75 & 569 & 27 & 0 & 54 & 533 & 19 & 0 & 67 & 548 & 14 & 0 & 63 & 611 & 28 & 0 & 62 & 550 & 21 \\
\hline
\end{tabular}

註：流：流血中 $\mathrm{H}$ 小体 $(\% \%$ ）促：促進法 $\mathrm{H}$ 小体（\%o）赤：赤血球数（万）網：絧状赤血球数（\%) 


\section{3. $20 c c 1$ 回脱血}

20cc 1 回脱血を行い第 4 日目までの経過を見ると 表 5 の通り，赤血球数は第 1 日目に最低值を示すが, 第4 日目には略々正常となる.稀状赤血球は脱血後第 4 日目までは漸增するが，これはやがて漸减してゆく
ことはその後の経過を見た他の系列の実験で知られ る.流血中H小体は全経過を通じて認められす，促進 法H小体は第 2 日目に最高となり，その後は减少して ゆき，回復は極めて速い.

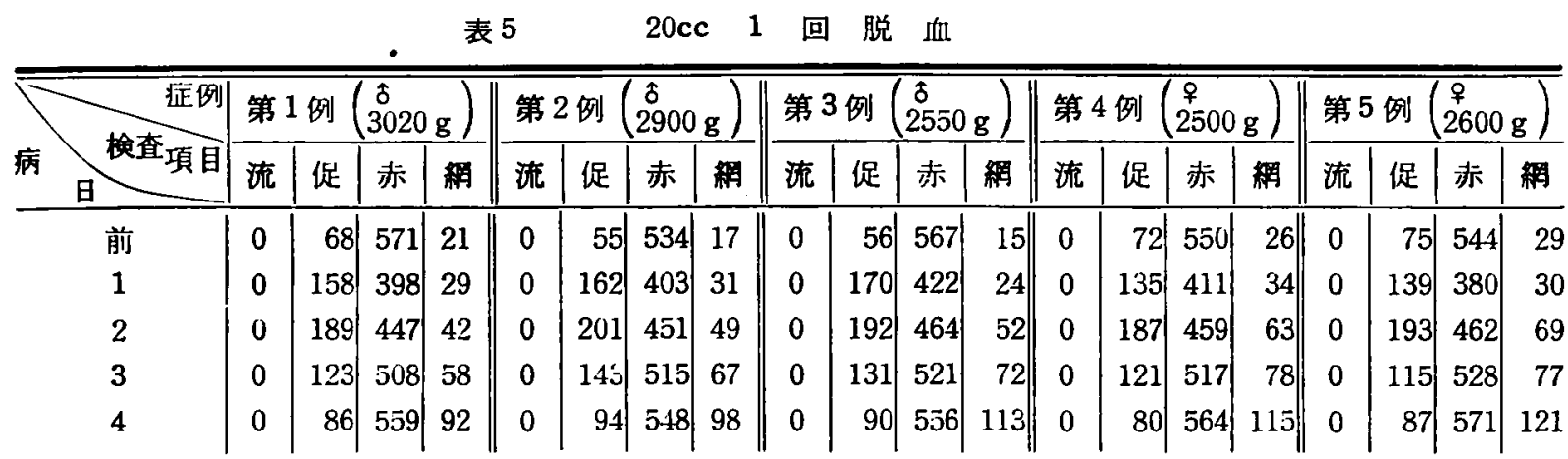

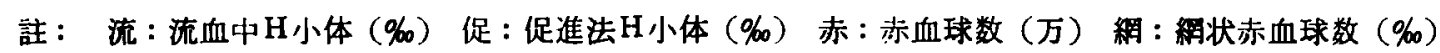

\section{40ec 1 回脱血}

40cc 1 回脱血を行うと家鬼の衰弱は相当萝だしい が，耐え得る．家鬼血液量は安東・田嶋ぜによれば 2 乃至 $3 \mathrm{~kg}$ の家鬼です $5.18 \%$ ，95.42\%であり，約 13 の脱血を行つたことになる.これによつて起る变化を 経過を追い第11乃至13日目まで钼察すると表 6 の通り て, 赤血球数の城少は第 2 日乃至 3 日目に最も強い。 これは組䄉液の血液への流入の時間的ずれによるもの であう. 網状赤血球数は第 4 日乃至 5 日目最高とな り，乙の後漸次減少してゆく．促進法H小体形成は第
1 日目より急增し，第 3 日目に最高となり，その後稍 々急激に減少してゆき，第10日目には平均 $80.8 \%$ とな り，脱血前の平均 $73.8 \%$ と有意差がなくなる，流血中 $\mathrm{H}$ 小体は赤血球内辺緑に細な点状物として第 2 日乃 至4日目にわつが見られ、ニールブラウ・ズルファ 一テでは明暸に染色せられ，メチール・ビオレットに も染色される顆粒であつて第 2 日目が最も多く，その 後减少するが，この顆粒の大きさは增大せず，又中心 部に向つて移動しない. 促進法H小体の最高値より流 血中H小体の最高値が先行する.

表6 $40 \mathrm{cc} 1$ 回 脱 血

\begin{tabular}{|c|c|c|c|c|c|c|c|c|c|c|c|c|c|c|c|c|c|c|c|c|}
\hline 症例 & 第 & & $\begin{array}{c}9 \\
2700\end{array}$ & & 第 & & $\begin{array}{c}q \\
2850\end{array}$ & & 第 & & $\begin{array}{l}9 \\
2200\end{array}$ & & & 例 & $\begin{array}{c}\delta \\
2200\end{array}$ & & 第 & 例 & $\begin{array}{l}\hat{0} \\
2350\end{array}$ & g) \\
\hline 日 & 流 & 促 & 赤 & 網 & 流 & 促 & 赫 & 积 & 流 & 促 & 赤 & 網 & 流 & 促 & 赤 & 網 & 流 & 促 & 赤 & 網 \\
\hline 前 & 0 & 77 & 525 & 28 & 0 & 61 & 543 & 25 & 0 & 68 & 560 & 13 & 0 & 82 & 574 & 15 & 0 & 81 & 581 & 19 \\
\hline 1 & 0 & 213 & 396 & 28 & 0 & 265 & 490 & 39 & 0 & 276 & 513 & 25 & 0 & 287 & 513 & 25 & 0 & 255 & 510 & 23 \\
\hline 2 & 4 & 297 & 320 & 39 & 5 & 305 & 341 & 32 & 6 & 317 & 362 & 34 & 7 & 321 & 336 & 43 & 8 & 315 & 331 & 40 \\
\hline 3 & 4 & 338 & 315 & 95 & 4 & 345 & 390 & 77 & 5 & 339 & 414 & 58 & 5 & 355 & 382 & 60 & 6 & 309 & 363 & 68 \\
\hline 4 & 1 & 295 & 395 & 128 & 3 & 311 & 412 & 112 & 2 & 306 & 395 & 105 & 2 & 305 & 452 & 74 & 3 & 287 & 406 & 188 \\
\hline 5 & 0 & 219 & 455 & 114 & 0 & 232 & 440 & 103 & 0 & 268 & 420 & 97 & 0 & 243 & 482 & 87 & 0 & 213 & 478 & 106 \\
\hline 6 & 0 & 223 & 480 & 101 & 0 & 201 & 480 & 96 & 0 & 217 & 461 & 86 & 0 & 213 & 493 & 82 & 0 & 187 & 527 & 96 \\
\hline 7 & 0 & 133 & 502 & 82 & 0 & 124 & 495 & 76 & 0 & 145 & 518 & 73 & 0 & 149 & 529 & 67 & 0 & 115 & 596 & 76 \\
\hline 8 & 0 & 121 & 520 & 64 & 0 & 105 & 495 & 69 & 0 & 115 & 552 & 71 & 0 & 101 & 528 & 64 & 0 & 97 & 596 & 69 \\
\hline 9 & 0 & 93 & 541 & 50 & 0 & 87 & 531 & 64 & 0 & 92 & 558 & 57 & 0 & 88 & 574 & 57 & 0 & 82 & 530 & 68 \\
\hline 10 & 0 & 86 & 560 & 38 & 0 & 72 & 549 & 52 & 0 & 90 & 566 & 46 & 0 & 73 & 598 & 42 & 0 & 83 & 548 & 52 \\
\hline 11 & 0 & 87 & 554 & 26 & 0 & 75 & 566 & 28 & 0 & 85 & 556 & 39 & 0 & 75 & 578 & 23 & 0 & 81 & 564 & 31 \\
\hline 12 & & 82 & & & & 75 & & & & 83 & & & & 73 & & & & 72 & & \\
\hline 13 & & 83 & & & & 73 & & & & 75 & & & & 71 & & & & 70 & & \\
\hline
\end{tabular}

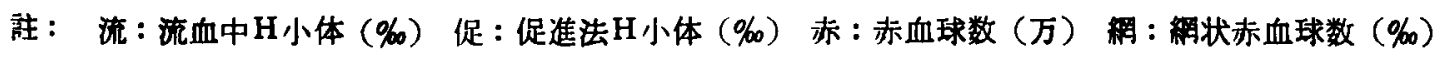


表 $7 \quad 15 \mathrm{cc}$ 毎 日, 2 㥜間脱血

\begin{tabular}{|c|c|c|c|c|c|c|c|c|c|c|c|c|c|c|c|c|c|c|c|c|}
\hline \multirow{2}{*}{ 病検查項目 } & \multicolumn{2}{|c|}{ 第 1 例 } & \multicolumn{2}{|c|}{$(2300 \mathrm{~g}$} & \multicolumn{2}{|c|}{ 第 2 例 ( } & \multicolumn{2}{|c|}{$\left(\begin{array}{ll}\hat{D} \\
2300 \mathrm{~g}\end{array}\right.$} & \multicolumn{2}{|c|}{ 第3 例 } & \multicolumn{2}{|c|}{$\begin{array}{ll}+9 \\
2000 \mathrm{~g}\end{array}$} & \multicolumn{2}{|c|}{ 第 4 例 } & \multicolumn{2}{|c|}{$(2400 \mathrm{~g}$} & \multicolumn{4}{|c|}{ 第5 例 $\left(\begin{array}{l}q \\
2850 \mathrm{~g}\end{array}\right)$} \\
\hline & 流 & 促 & 赤 & 秱 & 流 & 促 & 赤 & 稀 & 流 & 促 & 赤 & 網 & 流 & 促 & 赤 & 秱 & 流 & 促 & 赤 & 程 \\
\hline 前 & 0 & 37 & $|563|$ & 23 & 0 & 56 & 590 & 24 & 0 & 66 & $|560|$ & 26 & 0 & 65 & 620 & $17 \|$ & 0 & 62 & 618 & 16 \\
\hline 1 & 0 & 141 & 514 & 39 & 0 & 126 & 538 & 42 & 0 & 130 & 523 & 51 & 0 & 125 & 560 & 43 & 0 & 98 & 541 & 46 \\
\hline 2 & 0 & 192 & 481 & 63 & 0 & 163 & 489 & 71 & 0 & 171 & 470 & 68 & 0 & 190 & 501 & 66 & 0 & 162 & 498 & 63 \\
\hline 3 & 0 & 236 & 362 & $71 \|$ & 0 & 251 & 327 & 82 & 0 & 212 & 348 & 73 & 0 & 201 & 376 & 69 & 0 & 195 & 360 & 72 \\
\hline 4 & $\sigma$ & 254 & 342 & 86 & 0 & 275 & 326 & 83 & 0 & 223 & 361 & 76 & 0 & 206 & 344 & 72 & 0 & 214 & 325 & 78 \\
\hline 5 & 0 & 254 & 336 & $121 \|$ & 0 & 263 & 319 & 135 & 0 & 219 & 358 & 142 & 0 & 215 & 341 & 116 & 0 & 227 & 322 & 108 \\
\hline 6 & 0 & 262 & 341 & 176 & 0 & 277 & 306 & 164 & 0 & 225 & 349 & 175 & 0 & 215 & 338 & 163 & 0 & 230 & 320 & 156 \\
\hline 7 & 0 & 272 & 335 & 172 & 0 & 256 & 318 & 174 & 0 & 244 & 347 & 163 & 0 & 205 & 330 & 169 & 0 & 228 & 319 & 162 \\
\hline 8 & 0 & 263 & 339 & 156 & 0 & 264 & 317 & 163 & 0 & 238 & 331 & 159 & 0 & 214 & 328 & 160 & 0 & 219 & 321 & 167 \\
\hline 9 & 0 & 255 & 326 & 162 & 0 & 254 & 310 & $171 \|$ & 0 & 241 & 325 & 168 & 0 & 221 & 325 & 164 & 0 & 236 & 326 & 170 \\
\hline 10 & 0 & 264 & 329 & $161 \|$ & 0 & 263 & 308 & 168 & 0 & 243 & 321 & 154 & 0 & 226 & 320 & 167 & 0 & 231 & 318 & 172 \\
\hline 11 & 0 & 267 & 321 & 176 & 0 & 261 & 301 & 172 & 0 & 235 & 320 & 167 & 0 & 227 & 323 & 165 & 0 & 228 & 328 & 175 \\
\hline 12 & 0 & 259 & 320 & 169 & 0 & 255 & 298 & 165 & 0 & 238 & 325 & 170 & 0 & 230 & 310 & 169 & 0 & 232 & 320 & 165 \\
\hline 13 & 0 & 268 & 325 & 159 & 0 & 250 & 290 & 163 & 0 & 225 & 305 & 162 & 0 & 219 & 318 & 162 & 0 & 228 & 316 & 161 \\
\hline 14 & 0 & 237 & 321 & 163 & 0 & 226 & 301 & 157 & 0 & 201 & 310 & 168 & 0 & 179 & 317 & 171 & 0 & 180 & 307 & 163 \\
\hline 15 & 0 & 198 & 329 & 152 & 0 & 187 & 330 & 145 & 0 & 181 & 356 & 159 & 0 & 165 & 345 & 161 & 0 & 162 & 331 & 150 \\
\hline 16 & 0 & 167 & 338 & 142 & 0 & 151 & 336 & 138 & 0 & 152 & 342 & 146 & 0 & 132 & 344 & 156 & 0 & 137 & 345 & 148 \\
\hline 17 & 0 & 140 & 379 & 138 & 0 & 132 & 380 & 132 & 0 & 128 & 390 & 141 & 0 & 112 & 362 & 140 & 0 & 119 & 408 & 134 \\
\hline 18 & 0 & 103 & 421 & 105 & 0 & 116 & 435 & 127 & 0 & 97 & 456 & 130 & 0 & 92 & 467 & 127 & 0 & 94 & 465 & 119 \\
\hline 19 & 0 & 92 & 478 & 94 & 0 & 94 & 492 & 102 & 0 & 81 & 508 & 114 & 0 & 79 & 516 & 108 & 0 & 77 & 497 & 107 \\
\hline 20 & 0 & 82 & 521 & 76 & 0 & 79 & 537 & 79 & 0 & 63 & 551 & 80 & 0 & 62 & 522 & 72 & 0 & 58 & 530 & 70 \\
\hline 21 & 0 & 62 & 559 & 72 & 0 & 53 & 581 & 63 & 0 & 61 & 590 & 67 & 0 & 67 & 555 & 61 & 0 & 57 & 562 & 59 \\
\hline 22 & 0 & 57 & 603 & $60 \|$ & 0 & 59 & 621 & 52 & 0 & 57 & 615 & $51 \|$ & 0 & 63 & 590 & 53 & 0 & 69 & 586 & 50 \\
\hline 23 & 0 & 58 & 591 & 51 & 0 & 60 & 605 & 49 & 0 & 59 & 596 & 43 & 0 & 62 & 620 & 47 & 0 & 61 & 606 & 42 \\
\hline 28 & & & & 32 & & & & 21 & & & & 29 & & & & 26 & & & & 19 \\
\hline
\end{tabular}

註：流：流血中 $\mathrm{H}$ 小体 $(\%)$ 促：促進法 $\mathrm{H}$ 小体 $(\%)$ 赤: 赤血球数（万）網：網状赫血球数 $(\%)$

\section{5. 毎日10乃至 15c02週間脱血}

毎日10万至15ccの脱血を2週間にわたつて行い慢性 費血状態を作りその状態を覞察すると表 7 の通りで毎 日脱血を行つても赤血球数比極端な烝落現象等は見ら れない.第 3 日目急激に減少した赤血球数は，その後は 若干の変動をもつて300万台を緩やかに下降してゆく． 脱血を中止すると徐々に赤血球数は增加してゆき第20 日目には略々正常に回復する.網状赤血球は脱血䒚行 亏と醉次增加し第 6 日目一定の高さに達し爾後概社横 這い状態が続き，脱血を中止すると赤血球の增加状態 よりもゆるやかに下降してゆき第28日目には正常値と なる.流血中H小体は全期間を通して認められない。 促進法H小体は24時間後既に中等度の增加を示し爾後 の推移は赤血球数に反比例し第 3 日目より急激に增加 する.脱血の中止後は赫血球增加と反比例して隇少し てゆき第20日目の促進法H小体平均值は脱血前の平均
值と推計学的に有意差がなくなる。

以上 2 乃至 5 の脱血実験の結果について若干の考察 を加えると $5 \mathrm{cc}$ 及ひ 20cc 1 回脱血に於ては赤血球 の減少に応して促進法H小体の增减があるが，流血中 H小体は出現しない. 又10乃至 $15 \mathrm{cc}$ の連続脱血に於 ても流血中H小体悓られない，40cc の大量脱血に 於てのみ流血中 $\mathrm{H}$ 小体が出現する. 脱血の影整につい て考えられることは膜透過性の問题と稆内系機能 え 進")及び水血症であろう.これらの各組合せの強弱に よつて前記の差が出たものと考えられる. 又 40cc 脱 血洔に於ける流血中H小体最高值は促進法H小体の最 高値に先行するる様であり，他の実験では促進法H小 体最高値は赤血球数の最低値に稍々遅れている粎であ る.こ㣗によつて見ても流血中H小体と促進法H小体 の出現機序は巽ると云わればならない。 


\begin{tabular}{|c|c|c|c|c|c|c|c|c|c|c|c|c|c|c|c|c|c|c|c|c|}
\hline \multirow{2}{*}{ 病㛟查項目 } & \multicolumn{2}{|c|}{ 第 1 例 } & \multicolumn{2}{|c|}{$\left(\begin{array}{l}8 \\
2900 \mathrm{~g}\end{array}\right)$} & \multicolumn{2}{|c|}{ 第 2 例 } & \multicolumn{2}{|c|}{$\left(\begin{array}{l}9 \\
2400 \mathrm{~g}\end{array}\right)$} & \multicolumn{2}{|c|}{ 第3 例 } & \multicolumn{2}{|c|}{$\left(\begin{array}{l}\delta \\
2500 \mathrm{~g}\end{array}\right)$} & \multicolumn{2}{|c|}{ 第 4 例 } & \multicolumn{2}{|c|}{$\left(\begin{array}{ll} \\
2200 & \mathrm{~g}\end{array}\right)$} & \multicolumn{2}{|c|}{ 第 5 例 } & \multicolumn{2}{|c|}{$2300 \mathrm{~g}$} \\
\hline & 流 & 促 & 赤 & 秱 & 流 & 促 & 赤 & 粡 & 流 & 促 & 赤 & 網 & 流 & 促 & 赤 & 和 & 流 & 促 & 赤 & 網 \\
\hline 前 & 0 & 62 & 563 & 11 & 0 & 68 & 523 & 17 & 0 & 72 & 516 & 16 & 0 & 60 & 554 & 21 & 0 & 59 & 536 & 15 \\
\hline 1 & 47 & 163 & 548 & 16 & 33 & 152 & 514 & 15 & 20 & 148 & 498 & 17 & 39 & 170 & 547 & 18 & 56 & 169 & 544 & 13 \\
\hline 2 & 74 & 148 & 551 & 17 & 66 & 139 & 532 & 18 & 46 & 123 & 506 & 16 & 57 & 150 & 545 & 21 & 81 & 148 & 522 & 18 \\
\hline 3 & 26 & 121 & 568 & 13 & 13 & 102 & 526 & 18 & 9 & 122 & 513 & 15 & 14 & 137 & 565 & 20 & 52 & 129 & 532 & 15 \\
\hline 4 & 10 & 105 & & & 7 & 92 & & & 2 & 131 & & & 5 & 113 & & & 36 & 103 & & \\
\hline 5 & 3 & 93 & 553 & 14 & 2 & 87 & 561 & 16 & 0 & 98 & 522 & 15 & 1 & 86 & 564 & 19 & 4 & 79 & 537 & 17 \\
\hline 6 & 0 & 83 & & & 0 & 72 & & & 0 & 81 & & & 0 & 73 & & & 0 & 68 & & \\
\hline 7 & 0 & 74 & 562 & 16 & 0 & 63 & 543 & 14 & 0 & 75 & 526 & 13 & 0 & 70 & 571 & 17 & 0 & 63 & 548 & 13 \\
\hline
\end{tabular}

註：流：流血 $\mathrm{j} \mathrm{H}$ 小体（\%) 促：促進法 $\mathrm{H}$ 小体（\%o）赤：赤血球数（万）网：絧状赫血球数（\%)

$1 \%$ ェニールヒドラジン $1 \mathrm{cc}$ を耳静脈内に泩入 すると一激脈は隌赤色となるが，整時の後正常にな る. 此の聂合の赤血球变化の推移注表 8 の通りで流血 中H小体は第 1 日目より出現し第 2 日目に最高となり 第4 日乃至第 5 日目まで存在する. 赫血球内のH小体 は非常に小さく，約半数は球内周悢にあり，他の半数 は辺源より離れて存存する。この顆粒は增大せす，又 Heinzてりの記载した様に樹技状に突起を出す等の現 象も認めなかつた. 促進法H小体は第 1 日目最高とな り第7 日目には注射前に復した. 促進法H小体の大き さは殆んど全部中等大であり, 亦血球の辺縟より稍々 離㣗て中心奇りに存在する. 促進法を行つて赤血球外 に遊離したH小体もあるが函めて少数である．尔血球 数、网状赤血球数は 1 回のみの注射では殆ど影皚を認 めなかつた。流血中H小体が最高の第 2 日目既に促進 法H小体が稍々減少するのは榧めて興制ある現象で， 此の点に於ても両者の本態の相違が筧われるが，かか る現象はフェニールヒドラジンにより溶血を起さんと して未だ起さない状態の赤血球が促進法操作により崩 壊すること及ひ時間の经過に従い血中フェニールヒド ラシンの影签がうすれることによつて生ずると考えら れる.

\section{7. $2 \%$ ニニールヒトラジン loc 注射}

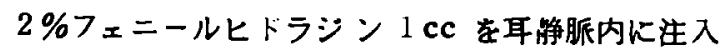
すると表 9 の通り流血中H小体は第 2 日目に最高とな り，第9日乃至12日目まで認められる。第 1 日目 $\mathrm{H}$ 小 体は小さく、完全な球形を呈せず，赫血球辺悢にある が第 2 日目には中型の球状を呈する样になり辺緑より 崔れて存在する様になるが，小体の周迅は軨倣が稍々 明䀧さを久く、第3 日目に至つて, 中等大球状の小体 の周囲は非常に明暸になる。しかし赤血球自体は污な
く、けば立つた様に見える、こ机は赤血球の表面に微 紐な点状物があり，この為浱淡が㴬しく一様に染まら ない為と思われる，H小体を含有しない赫血球はこの 椂にならないから，染色液又は手技の䦗題ではなく：H 小体含有赫血球そのものに原因がある.恐らくフェニ ールヒドラジンによる䞔血球膜の損笏によるものであ らう.中等大迄に発達したH小体は大体その大きさの まま减少してゆき:第1例に於ては第12日目，第3 例は 第10日目:他は第 9 日目迄認めた 促進法H小体は第 1 日乃至 3 日目最高値をとるが，この場合H小体は大部 分 1 個の赤血球に 1 個であり, 殆んど中等大以上とな り，赤血球辺緑より中心部人向つたもの，辺緑の内㑢 にあるもの，外側にあるもの，樹枝状をなして赤血球 より分離しかかつたもの，或は测定数には加えなかつ たが明らかに赤血球より分離したと思われるものも多 数あり，又赤血球が崩壊した為に遊離した小体も多い ものと思われる. 又赫血球内にH小体のスがあり，内 容物がなく赤血球陰影となつているものが多い.これ はH小体が赤血球内容物と関係を有することを示すも のとも解される.今日H小体は赫血球膜の变性したも のであるという説"゙'が大势在占めており，Jang102

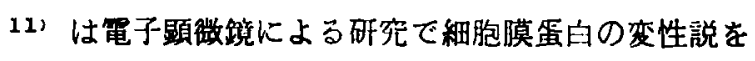
支持したが，これでは湿潤血液標本に於けるH小体の ブラウン運動7122を説明することが困 難であり，

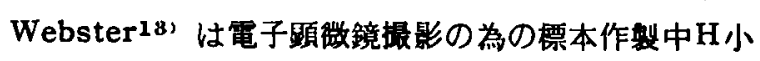
体の構造に变化が加わることも充分ありうると云つて いる所からも細胞膜变性説のみで全部が解明出来るか けではない，第 7 日乃至 8 日目の促進法H小体数平均 値と注射前の夫れの平均值を比へると推計学的に有意 差があり前者が多いが流血中H小体が存在するにも拘 わらす促進法H小体平均值が注射前の大れの平均值に 
表 $92 \%$ $2 \%$ ー ルヒドラヂン 1 cc 注射

\begin{tabular}{|c|c|c|c|c|c|c|c|c|c|c|c|c|c|c|c|c|c|c|c|c|}
\hline \multirow{2}{*}{ 病㭘查項目 } & \multicolumn{2}{|c|}{ 第 1 例 (} & \multicolumn{2}{|c|}{$\left(\begin{array}{l}\hat{\delta} \\
2800 \mathrm{~g}\end{array}\right)$} & \multicolumn{4}{|c|}{ 第 2 例 $\left(\begin{array}{c}\overrightarrow{3} \\
2800 \mathrm{~g}\end{array}\right)$} & \multicolumn{2}{|c|}{ 第 3 例 } & \multicolumn{2}{|c|}{$2400 \mathrm{~g}$} & \multicolumn{2}{|c|}{ 第 4 例 } & \multicolumn{2}{|c|}{$\left(\begin{array}{l}9 \\
2400 \mathrm{~g}\end{array}\right)$} & \multicolumn{2}{|c|}{ 第 5 例 } & \multicolumn{2}{|c|}{$\left(\begin{array}{l}q \\
2560 \\
25\end{array}\right)$} \\
\hline & 流 & 促 & 赤 & 粡 & 流 & 促 & 赤 & 網 & 流 & 促 & 赤 & 網 & 流 & 促 & 赤 & 網 & 流 & 促 & 赤 & 網 \\
\hline 前 & & 72 & 562 & 24 & 0 & 66 & 579 & 29 & 0 & 68 & 598 & 22 & 0 & 78 & 602 & 31 & 0 & 81 & 549 & 33 \\
\hline 1 & 126 & 136 & 519 & 52 & 89 & 279 & 526 & 49 & 113 & 236 & 556 & 33 & 96 & 210 & 532 & 62 & 83 & 191 & 520 & 76 \\
\hline 2 & 163 & 216 & 462 & 61 & 116 & 214 & 471 & 56 & 154 & 271 & 457 & 46 & 126 & 198 & 471 & 83 & 98 & 278 & $460 \mid$ & 89 \\
\hline 3 & 145 & 276 & 420 & 62 & 94 & 182 & 417 & 63 & 131 & 212 & 397 & 48 & 104 & 176 & 408 & 86 & 72 & 224 & 400 & 83 \\
\hline 4 & 130 & 244 & 372 & 77 & 68. & 165 & 362 & 69 & 113 & 188 & 353 & 52 & 89 & 140 & 376 & 89 & 62 & 199 & 381 & 80 \\
\hline 5 & 113 & 103 & 339 & 72 & 52 & 142 & 406 & 72 & 101 & 97 & 412 & 56 & 53 & 120 & 352 & 91 & 43 & 148 & $|362|$ & 92 \\
\hline 6 & 119 & 110 & 396 & 72 & 44 & 164 & 435 & 70 & 78 & 106 & 456 & 52 & 46 & 119 & 398 & 90 & 27 & 152 & 327 & 97 \\
\hline 7 & 86 & 120 & 438 & 79 & 28 & 112 & 451 & 82 & 54 & 94 & 453 & 67 & 21 & 98 & 448 & 98 & 15 & 121 & 386 & 103 \\
\hline 8 & 75 & 90 & 476 & 92 & 24 & 89 & 483 & 80 & 31 & 81 & 476 & 78 & 16 & 83 & 492 & 101 & 10 & 90 & 468 & 131 \\
\hline 9 & 50 & 87 & 502 & 75 & 6 & 77 & & & 14 & 87 & 518 & 63 & 8. & 81 & 538 & 90 & 3 & 86 & 512 & 125 \\
\hline 10 & 36 & 76 & & 70 & 0 & 86 & 512 & 63 & 5 & 69 & 543 & 68 & 0 & 84 & 562 & 61 & 0 & 83 & 556 & 96 \\
\hline 11 & 19 & 79 & 532 & 63 & 0 & 83 & 541 & 52 & 0 & 72 & 541 & 51 & 0 & 80 & 569 & 47 & 0 & 79 & 549 & 83 \\
\hline 12 & & 74 & & & & 78 & & & 0 & 77 & & & 0 & 75 & & & 0 & 79 & & \\
\hline 13 & 0 & 78 & 564 & 52 & 0 & 82 & 562 & 30 & 0 & 76 & 571 & 33 & 0 & 76 & 582 & 49 & 0 & 68 & 571 & 67 \\
\hline 14 & 0 & 72 & & & 0 & 77 & & & 0 & 67 & & & 0 & 74 & & & 0 & 72 & & \\
\hline 15 & & & 559 & 40 & & 7 & 584 & 31 & 0 & 62 & 632 & 22 & & 70 & 596 & 34 & 0 & 73 & 568 & 48 \\
\hline
\end{tabular}

註：流：流血中 $\mathrm{H}$ 小体 $(\%)$ 促：促進法 $\mathrm{H}$ 小体 $(\%)$ 赤：赤血球数（万）網：網状赫血球数 $(\% \%)$

近い数価を示したのは流血中H小体の促進法による崩 㙘を無視するわけにはゆかない. 第10日目に至つて注 射前と平均値に有意差がなくなる．赤血球数は第 4 日 乃至 6 日目最少となり，その後徐々に增加し，第10日 目正常値となるが第13日目には平均値に於て注射前と 有意差がなくなる．絧状赤血球は数日幄れ第 8 日目に 平均值は最高となり，乙の後徐々に減少する。第 4 日 乃至 6 日目促進法 $\mathrm{H}$ 小体が流血中H小体より少いこと がある.この時期流血中H小体数はかなり多く存在し ているところから，H小体含有赤血球中多くのものが 促進法操作中に破壤さ机残存 $\mathrm{H}$ 小体と流血中 $\mathrm{H}$ 小体 有しない赤血球に促進法によりH小体が形成されたも のとの和が促進法H小体として剆定されることとな り, 従つて促進法操作により流血中 $\mathrm{H}$ 小体含有赤血球 が壊れ易いものが多いこと及び流血中H小体非含有赤 血球に促進法によりH小体を形成するものが比較的少 くなつていることが分る。

この実䮖に於ては赤血球数と促進法 $\mathrm{H}$ 小体数は平行 関俰にない。即ち赤血球数の最低が第 4 日目であり， 促進法H小体の最高值が第2 日目である。このことは 赤血球の減少といら要装よりも，注入されたフェニー ルヒトラジンの影济の方が促進法H小体形成にも強く 作用することを現わしている。

8. $5 \%$ フェニールヒドラジン lec 注射

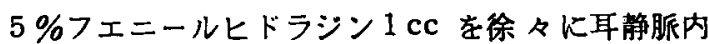
に注入すると血管は直ちに暗赤色となるが流血中 $\mathrm{H}$ 小 体は認められない。6 時間後には流血中 $\mathrm{H}$ 小体は出現 しており顆粒は中等大で輪倣は極めてぼやりしてい る. 注射後24時間で流血中 $\mathrm{H}$ 小体数は最高となり，第 2 日目には小体は赤血球内の大半を占める様になり， 山凸がある様に見える. 恐らく 1 個の小体ではなく数 個のものが融合してその様に見えるのであろう. 又 H 小体の大小不同が甚だしく，これは消失する迄変らな い。而して流血中 $\mathrm{H}$ 小体性第 7 日乃至 8 日目まで存在 する.赤血球外に遊離した小体も亦多量に認められる か、これは樹枝状になりその後赤血球から遊離したと 考えるより，赤血球の急激な減少より見てその崩壊に より生じたるものと考える方が妥当であろう．表10の 通り第 1 日目と第 2 日目の流血中H小体出現率は略々 同じであるが，赤血球数は非常に隇少していることよ り第 1 日目に現われた $\mathrm{H}$ 小体含有赤血球は相当数崩壤 して:その為赤血球減少を来し，第 2 日目のH小体含有 赤血球は少新たに生成したと考えるのが妥当であろ 3. その後流血中 H小体含有赤血球数㤹做诚し, 赤血 球数は第 3 日目以後あまり変らすむしろ增加してゅく ことは，H小体の新生はもはやなく，H小体含有赤血 球は崩鉷してゆき，新生赤血球が出現し始めたことを 示している. 赤血球数は第 3 日乃至 5 日目最低とな 
表 $10 \quad 5 \%$ ○ュニールヒドラヂン $1 \mathrm{cc}$ 注射

\begin{tabular}{|c|c|c|c|c|c|c|c|c|c|c|c|c|c|c|c|c|c|c|c|c|}
\hline 症 例 & 第例 & & $\left(\begin{array}{l}9 \\
3000\end{array}\right.$ & & 第 2 & 例 & 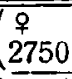 & & 第 3 & 例 & $\left(\begin{array}{l}q \\
2400\end{array}\right.$ & & 第 4 & & $\left(\begin{array}{c}0 \\
2300\end{array}\right.$ & $0 \mathrm{~g})$ & 第 5 & 5 例 & $\left(\begin{array}{c}\delta \\
2500\end{array}\right.$ & g) \\
\hline 㝵 & 流 & 促 & 赤 & 稍 & 流 & 促 & 赤 & 網 & 流 & 促 & 标 & 網 & 流 & 促 & 赤 & 網 & 流 & 促 & 赤 & 網 \\
\hline 前 & & 64 & 571 & 32 & 0 & 69 & 589 & 27 & 0 & 79 & $|612|$ & 29 & 0 & 81 & 532 & 21 & & 96 & 581 & 19 \\
\hline 1 & 439 & 934 & 471 & 52 & 516 & 876 & 491 & 44 & 416 & 912 & 487 & 56 & 421 & 925 & 425 & 47 & 638 & 880 & 465 & 48 \\
\hline 2 & 426 & 930 & 335 & 63 & 508 & 892 & 356 & 61 & 407 & 876 & 357 & 51 & 410 & 866 & 342 & 59 & 593 & 875 & 338 & 64 \\
\hline 3 & 204 & 821 & 276 & 84 & 254 & 801 & 304 & 78 & 198 & 812 & 312 & 96 & 208 & 790 & 301 & 76 & 279 & 786 & 287 & 74 \\
\hline 4 & 112 & 726 & 290 & 82 & 133 & 512 & 261 & 80 & 98 & 732 & 256 & 89 & 102 & 607 & 282 & 79 & 142 & 621 & 263 & 72 \\
\hline 5 & 28 & 477 & 325 & 92 & 43 & 421 & 297 & 87 & 17 & 463 & 293 & 97 & 24 & 381 & 267 & 92 & 50 & 405 & 314 & 86 \\
\hline 6 & 12 & 410 & 338 & 93 & 19 & 224 & 341 & 95 & 10 & $|237|$ & 342 & 96 & 8 & 209 & 356 & 98 & 17 & 248 & 362 & 92 \\
\hline 7 & & 215 & 376 & 120 & 6 & 144 & 385 & 98 & 4 & 138 & 394 & 103 & 2 & 111 & 374 & 110 & 9 & 126 & \begin{tabular}{|l|l}
399 \\
\end{tabular} & 108 \\
\hline 8 & & 138 & 407 & 113 & & 87 & 424 & 108 & 0 & 92 & 438 & 118 & & 72 & 416 & 146 & & 83 & 447 & 99 \\
\hline 9 & 0 & 76 & 463 & 97 & 0 & 82 & 481 & 94 & 0 & 81 & 496 & 112 & & 76 & 472 & 126 & 0 & 84 & 506 & 109 \\
\hline 10 & & 72 & 521 & 86 & & 79 & 536 & 82 & & 69 & 544 & 98 & & 69 & 533 & \begin{tabular}{|l|l|} 
& 98
\end{tabular} & & 87 & 557 & 89 \\
\hline 11 & & 66 & 534 & 76 & & 68 & 551 & $81 \|$ & & 65 & 592 & 90 & & 79 & 581 & 75 & & 81 & 561 & 74 \\
\hline 12 & & 68 & 546 & 72 & & 67 & 572 & 79 & & 66 & 590 & 83 & & 77 & 576 & 69 & & 79 & 553 & 52 \\
\hline 13 & & 66 & 567 & 63 & & 67 & 570 & 67 & & 68 & 607 & 64 & & 78 & 577 & 51 & & 8 & 563 & 41 \\
\hline
\end{tabular}

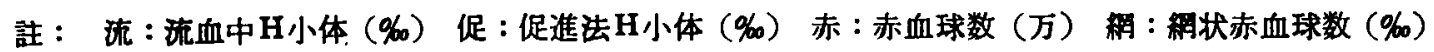

表 11

$1 \%$ $1 \%$ ルヒドラチン1 cc5日間連続泩射

\begin{tabular}{|c|c|c|c|c|c|c|c|c|c|c|c|c|c|c|c|c|c|c|c|c|}
\hline (症 例 & 第 1 & & $\begin{array}{l}\hat{0} \\
2300\end{array}$ & & 第 2 & & $\stackrel{8}{2550}$ & & 第 3 & & $\stackrel{9}{2400}$ & & 第 4 & 例 & 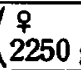 & & 第 5 & 例 & 2900 & \\
\hline 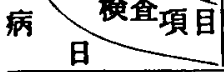 & 流 & 促 & 赤 & 稀 & 流 & 促 & 赤 & 綢 & 流 & 促 & 赤 & 檞 & 流 & 促 & 赤 & 阙 & 流 & 促 & 赤 & 秝 \\
\hline 前 & 0 & 53 & 542 & 17 & 0 & $\dot{62}$ & 561 & 21 & 0 & 70 & 532 & 16 & 0 & 71 & 513 & 13 & 0 & 62 & 579 & 19 \\
\hline 1 & 21 & 153 & 540 & 19 & 34 & 169 & 558 & 23 & 46 & 149 & 535 & 14 & 42 & 145 & 505 & 18 & 57 & 162 & 560 & 16 \\
\hline 2 & 123 & 346 & 342 & 38 & 145 & 410 & 387 & 42 & 156 & 387 & 364 & 41 & 132 & 393 & 360 & 36 & 168 & 425 & 390 & 51 \\
\hline 3 & 653 & (2) & 251 & 43 & 579 & & 266 & 44 & 624 & $\forall a$ & 247 & 51 & 687 & & 224 & 50 & 701 & $\forall \nexists 1$ & 272 & 57 \\
\hline 4 & 783 & 恻 & 233 & 76 & 624 & 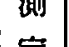 & 235 & 68 & 791 & 期 & 224 & 79 & 745 & 恻 & 218 & 76 & 772 & 它 & 247 & 81 \\
\hline 5 & $7 \overline{5} 1$ & 足 & 205 & 143 & 732 & 正 & 211 & 136 & 643 & 正 & 197 & 159 & 735 & 足 & 201 & 98 & 698 & 足 & 225 & 147 \\
\hline 6 & 691 & & 227 & 176 & 678 & & 215 & 191 & 654 & & 204 & 194 & 725 & & 213 & 192 & 709 & & 224 & 202 \\
\hline 7 & 652 & 能 & 216 & 193 & 601 & 狊E & 220 & 196 & 595 & 能 & 209 & 187 & 632 & 能 & 198 & 193 & 611 & 能 & 213 & 200 \\
\hline 8 & 456 & 624 & 224 & 183 & 442 & 699 & 227 & 174 & 471 & 633 & 217 & 185 & 429 & 601 & 208 & 176 & 492 & 701 & 221 & 187 \\
\hline 9 & 257 & 421 & 238 & 194 & 306 & 538 & 226 & 182 & 241 & 464 & 225 & 190 & 285 & 401 & 216 & 175 & 337 & 459 & 228 & 199 \\
\hline 10 & 52 & 145 & 328 & 164 & 78 & 123 & 317 & 142 & 64 & 187 & 326 & 125 & 42 & 204 & 309 & 118 & 92 & 198 & 311 & 151 \\
\hline 11 & 17 & 97 & 372 & 142 & 14 & 92 & 356 & 141 & 15 & 105 & 348 & 116 & 11 & 113 & 381 & 103 & 16 & 99 & 378 & 124 \\
\hline 12 & 6 & 86 & 392 & 97 & 9 & 82 & 387 & 86 & 7 & 97 & 405 & 96 & 5 & 77 & 423 & 89 & 6 & 63 & 451 & 104 \\
\hline 13 & 2 & 69 & 452 & 75 & 3 & 72 & 445 & 72 & 0 & 87 & 481 & 74 & 0 & 63 & 486 & 63 & 2 & 66 & 496 & 70 \\
\hline 14 & 0 & 59 & 501 & 64 & 0 & 66 & 496 & 68 & 0 & 77 & 525 & 70 & 0 & 65 & 544 & 53 & 0 & 67 & 563 & 62 \\
\hline 15 & 0 & & 556 & 46 & 0 & & 558 & 33 & 0 & & 335 & 41 & 0 & & 532 & 29 & 0 & & 569 & 47 \\
\hline 16 & 0 & & 549 & 37 & 0 & & 561 & 32 & 0 & & 542 & 32 & 0 & & 538 & 21 & 0 & & 576 & 29 \\
\hline 20 & 0 & & 562 & 15 & 0 & & 559 & 21 & 0 & & 547 & 13 & 0 & & 526 & 18 & 0 & & 587 & 24 \\
\hline
\end{tabular}

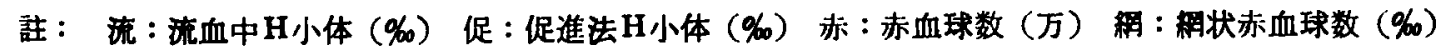

り，その後比較的急速に增加し始め第11日目には注射 前の平均値に回復する。編状赤血球は第 8 日乃至10日 目取高値をとるが第13日目台高値である.赤血球数が
正常となつても，台網状赤血球が高値を示すのは此の 時期血色絭の恢復が末だ充分でない為赤血球の新生が 綂く為であろう. 而して 4 乃至 6 週後には正常値とな 
る. 促進法に於て出現するH小体は非常に高 值を示 し、第 1 日乃至 2 日目最高值となり，第 9 日目には注 射前の平均値と有意差がなくなるが血球より遊離して 存在する小体も哂めて多く形態的にも流血中 $\mathrm{H}$ 小体と は異つている. 前述の如く凹凸あり, 数個虽合した様 に見え，大きさも赤血球の将乃至将大となり，大小不 同もある流血中H小体と異り, 促進法H小体は小さく 陯廟の明暸な球状を呈するものが多く、赤血球辺線よ り稍々離れて存在する.これは促進法て流血中にあつ たH小体含有赤血球が大半崩壤し，毒物に損鹪された がH小体が出来なかつた赤血球, 及び新生赤血球に, 新たに促進法てH小体が形成されたものと思われる. しかし崩壊しなかつた流血中H小体含有赤血球に於て はH小体は益々大きくなつてゆく様であるがこの数は わすかである.

\section{9. $1 \%$ ฯニールヒドラジン 5 日間逗繶注射}

1 回注射のみではあまり変化を来さなかつた $1 \%$ フ エニールヒドラジン $1 \mathrm{cc}$ を耳静脈に 1 日 1 回 5 日間 連続注射してその影管を見た所, 表11の通り流血中H 小体は第 3 日目位より急速に增加し，網状赤血球にも 認められる．H小体の大きさは可成大きく赤血球の1/4 乃至13位を占める大きさとなる．乙の減少は泩射の中 止と共に始まり,第 8 日目以後急激となり第13日乃至
14日目には認めない様になる.促進法H小体は第 3 日 目から第 7 日目迄の間は赤血球の崩填が甚だしい為测 定不能であつた. 第 8 日目及ひ第 9 日目赤血球数の娍 少の為, 促進法 $\mathrm{H}$ 小体は高值となるが, 赤血球减少, 流血中 $\mathrm{H}$ 小体含有赤血球崩嘖の為\%による数值に比較 乙絶対数は少いと云える. 赤血球は 1 回大量注射の場 合よりも隇少が甚だしく，整く200万台を横這いした 後第10日目頃より徐々に增加してゆく，絴状赤血球は 第 5 日目頃より急增し，平均値では第 7 日目に最高と なり:第10日目頃より減少し始める.促進法 $\mathrm{H}$ 小体の平 均値は第13日目に正常範囲に回復する. 赤血球数は第 15日目, 絧状赤血球数は第20日目に平均値が泩射前の 平均値と有意美がなくなる. 測定不能の部分を除いて 流血中 $\mathrm{H}$ 小体と促進法 $\mathrm{H}$ 小体は平行状態にある様で るが, 内容は 8 の実験と同様流血中 $\mathrm{H}$ 小体含有赤血球 は大半崩壤して促進法では新たに小体が形成されてい るものが多い.

10. $1 \%$ 塩酸七ドロキシラミン lec 注射

$1 \%$ 塩酸ヒドロキシラミン耳静脈内に注入する時, 流血中に現われる $\mathrm{H}$ 小体の輪敫は最初から明暸であ り，赤血球边緑より稍々離孔て存在し，赤血球自体は フェニールヒドラジンを法射した場合の赤血球より美 麗である.流血中H小体は $2 \%$ フェニールヒドラシン

表 $121 \%$ 塩酸ヒドロキシラミン $1 \mathrm{cc}$ 注射

\begin{tabular}{|c|c|c|c|c|c|c|c|c|c|c|c|c|c|c|c|c|c|c|c|c|}
\hline 1-症 例 & 第 1 & 例 & $\stackrel{9}{9}$ & & 第 2 & 例 & $\begin{array}{r}9 \\
2900\end{array}$ & & 第 3 & & $\left(\begin{array}{l}q \\
2350\end{array}\right.$ & & 第 4 & 例 & $\begin{array}{l}\delta \\
2250\end{array}$ & & 第 5 & 例 & $\begin{array}{c}\hat{\delta} \\
2500\end{array}$ & \\
\hline 病 每㿼項目 & 流 & 促 & 赤 & 秝 & 流 & 促 & 赤 & 網 & 流 & 促 & 赤 & 網 & 流 & 促 & 赤 & 程 & 流 & 促 & 赤 & 網 \\
\hline 前 & 0 & 60 & 563 & 27 & 0 & 64 & 542 & 19 & 0 & 72 & 588 & 16 & 0 & 73 & 621 & 21 & 0 & 71 & 577 & 20 \\
\hline 1 & 208 & 386 & 507 & 25 & 203 & 271 & 496 & 28 & 244 & 334 & 506 & 30 & 218 & 211 & 514 & 29 & 232 & 289 & 516 & 32 \\
\hline 2 & 276 & 376 & 443 & 48 & 225 & 251 & 420 & 42 & 281 & 350 & 425 & 55 & 245 & 274 & 434 & 42 & 277 & 257 & 447 & 34 \\
\hline 3 & 246 & 169 & 412 & 70 & 176 & 206 & 460 & 74 & 136 & 377 & 406 & 87 & 187 & 205 & 405 & 63 & 205 & 218 & 415 & 50 \\
\hline 4 & 194 & 112 & 386 & 95 & 131 & 101 & 375 & 78 & 49 & 244 & 387 & 96 & 132 & 144 & 373 & 98 & 141 & 178 & 372 & 103 \\
\hline 5 & 95 & 120 & 338 & 140 & 111 & 96 & 315 & 79 & 30 & 221 & 325 & 104 & 105 & 121 & 345 & 103 & 113 & 169 & 322 & 117 \\
\hline 6 & 65 & 114 & 403 & 144 & 40 & 110 & 382 & 95 & 8 & 209 & 396 & 132 & 63 & 110 & 372 & 112 & 49 & 132 & 385 & 102 \\
\hline 7 & 31 & 95 & 462 & 138 & 11 & 98 & 446 & 101 & 2 & 164 & 451 & 115 & 14 & 101 & 445 & 105 & 15 & 105 & 453 & 116 \\
\hline 8 & 9 & 98 & 486 & 88 & 5 & 93 & 491 & 83 & 0 & 148 & 479 & 93 & 3 & 98 & 488 & 121 & 7 & 90 & 469 & 136 \\
\hline 9 & 4 & 94 & 490 & 73 & 0 & 87 & 506 & 80 & 0 & 117 & 483 & 81 & 0 & 96 & 476 & 72 & 0 & 83 & 454 & 84 \\
\hline 10 & 0 & 91 & 499 & 65 & 0 & 90 & 496 & 77 & 0 & 96 & 433 & 72 & 0 & 87 & 511 & 48 & 0 & 80 & 506 & 53 \\
\hline 11 & 0 & 89 & 533 & 55 & 0 & 86 & 538 & 52 & 0 & 91 & 465 & 48 & 0 & 79 & 528 & 47 & 0 & 72 & 526 & 42 \\
\hline 12 & 0 & 83 & & & 0 & 79 & & & 0 & 76 & & & 0 & 71 & & & 0 & 68 & & \\
\hline 13 & 0 & 70 & & & 0 & 80 & & & 0 & 70 & & & 0 & 69 & & & 0 & 67 & & \\
\hline 14 & 0 & 71 & & & 0 & 70 & & & 0 & 72 & & & 0 & 70 & & & 0 & 69 & & \\
\hline 15 & 0 & 73 & 573 & 26 & 0 & 65 & 559 & 21 & 0 & 74 & 568 & 18 & 0 & 71 & 587 & 25 & 0 & 72 & 545 & 14 \\
\hline
\end{tabular}

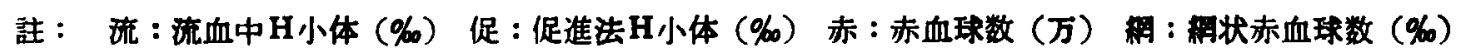


$1 \mathrm{cc}$ 静过の場合より多く壮現する．表12の通り流血 中H小体は第 2 日目に最高となり，乙の後急速に減少 して行くが第 7 日乃至 9 日目迄流血中に認められる. 而して略々1個の赫血球に 1 個の小体が出現してい ろ. 赤血球数は第 5 日目最低となり，その後筑䏴し第

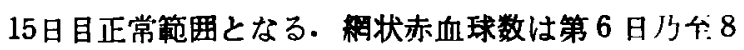
日目最高となり，乙の後衙次减少し，第15日目には注 射前と有意差がなくなる。一般に促進法に於ては流血 中H小体含有赤血球の破壊されるものもあるか，本実 蕀に於てはかかるものは少数であり，流血中にあつた H小体は益々大きくなり，H小体を含有しなかつた赤 血球以小さな小体が形成される。 ただ第 2 例では第 4 日目の促進法H小体が流血中H小体より減少してい る.こ机は本例では流血中H小体含有赤血球が促進法 の操作により破坡されやすい状熊にあつたことを示す ものである. 又第 3 例の流血中 $\mathrm{H}$ 小体は第 1 日目の出 現率及ひ最高出現率共に他症例より多いに拘らずもの 减少乃至消失は他症例よりも急激で早い。既に Cruz 1"は流血中H小体は赫血球の崩㙘したものと共に稀 内系で賁喰されることを示しているので本例では小 体の除去機能恐らく Heinz ${ }^{15)}$ 以来興味を持たれてい る秝内系機能特に佣䑏の機能が充進していた為と解す へきであろう．之に反し促進法H小体の出現率は他应. 例と変らない。これはH小体に関係するとされている

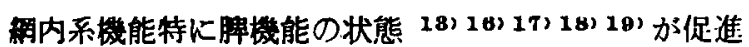
法H小体形成には関係がないことを示している。

\section{1. $5 \%$ 埴酸ヒドロキシラミン $1 \mathrm{ce}$ 注射}

$5 \%$ 塩酸ヒドロキシラミン $1 \mathrm{cc}$ を耳静脈内に注入 すると表13の通り赤血球は第 2 日目に既に急激な減少 を示す．流血中 $\mathrm{H}$ 小体は第 1 日目に最高となり，第 9 日乃至10日目迄認め5れ，5\%フェニールヒドラジン $1 \mathrm{cc}$ 注射の晴合より第 1 日目の出現率の平均值は有 意差をもつて大きいが 1 個の赤血球に出現した $\mathrm{H}$ 小体 は多いもので 7 乃至 8 個. 少いもので 1 個. 普通 3 乃 台 4 倜であり，それが倜々に明暸に区別出来る.この 点 $5 \%$ フェニールヒドラジン'1 cc 静泩時数個の小体 が融合した樣な像を呈した場合と非常に異る。赤血球 数と流血中 $\mathrm{H}$ 小体含有赤血球数との関係については 5 $\%$ \%エニールヒドラジン $1 \mathrm{cc}$ 静注の場合と同様なこ とが言える. 即ち第 1 日に出現した $\mathrm{H}$ 小体含有赤血球 は崩壊が激しくその為第 2 日目赤血球の急激な瑊少を 来す。第 2 日目流血中H小体加第 1 日目とあまり変 5 ないのに，新たに形成されたからである.H小体数は \%であるから平均值を絶対数に換算して見ると第 1 日 目赫血球の平均値 414.6万. 流血中 $\mathrm{H}$ 小体含有赤血球 は平均 $624.2 \%$ であるから第 1 日目血液 $1 \mathrm{~mm}^{3}$ 中約 259 万となり，第 2 日目赤血球平均 286 万，流血中H小 体含有赫血球平均 $610.8 \%$ であるから第 2 日目血液 1 $\mathrm{mm}^{3}$ 中約 175 万となる. 従つてその間の絶対数の诚 少は㽎だしい，第 1 日目及び第 2 日目に赤血球の新生 なくH小体を含有しない赤血球は崩嫂しなかつたと仮 定して模型的に考える時，第 2 日目には第 1 日目にH

表 13

$5 \%$ 篮酸ヒドロキシラミン $1 \mathrm{cc}$ 注射

\begin{tabular}{|c|c|c|c|c|c|c|c|c|c|c|c|c|c|c|c|c|c|c|c|c|}
\hline 应 例 & 第 1 & & $\begin{array}{l}\hat{D} \\
2350\end{array}$ & & 第2 & & 2600 & & 第 3 & & $\begin{array}{l}\stackrel{9}{9} \\
2250\end{array}$ & & 第 4 & 例 & $\begin{array}{l}9 \\
2450\end{array}$ & & 第 5 & 例 & $\begin{array}{l}\stackrel{9}{2} \\
2850\end{array}$ & \\
\hline 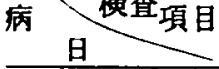 & 流 & 促 & 赤 & 網 & 流 & 促 & 赤 & 和 & 流 & 促 & 赤 & 網 & 流 & & 赤 & 綱 & 流 & 促 & 赤 & 網 \\
\hline 前 & 0 & 52 & 575 & 33 & 0 & 69 & 564 & 19 & 0 & 65 & 582 & 27 & 0 & 72 & 577 & 26 & 0 & 61 & 549 & 18 \\
\hline 1 & 631 & 892 & 439 & 59 & 645 & 916 & 426 & 63 & 606 & 930 & 432 & 54 & 597 & 920 & 382 & 54 & 642 & 872 & 394 & 51 \\
\hline 2 & 612 & 843 & 283 & 67 & 618 & 855 & 276 & 68 & 621 & 848 & 295 & 79 & 590 & 851 & 300 & 66 & 613 & 831 & 276 & 65 \\
\hline 3 & 392 & 666 & 294 & 84 & 382 & 641 & 263 & 82 & 395 & 606 & 289 & 91 & 382 & 635 & 277 & 69 & 401 & 613 & 281 & 79 \\
\hline 4 & 192 & 519 & 275 & 89 & 205 & 477 & 264 & 83 & 190 & 481 & 247 & 87 & 189 & 493 & 269 & 91 & 178 & 514 & 242 & 92 \\
\hline 5 & 140 & 478 & 235 & 97. & 132 & 423 & 223 & 103 & 145 & 435 & 218 & 98 & 147 & 460 & 226 & 98 & 150 & 469 & 259 & 97 \\
\hline 6 & 127 & 220 & 374 & 93 & 116 & 204 & 313 & 99 & 78 & 198 & 298 & 104 & 119 & 213 & 306 & 105 & 129 & 235 & 389 & 93 \\
\hline 7 & 62 & 174 & 405 & 105 & 72 & 183 & 385 & 103 & 28 & 166 & 376 & 112 & 39 & 182 & 415 & 111 & 63 & 191 & 452 & 107 \\
\hline 8 & 29 & 128 & 448 & 140 & 31 & 135 & 468 & 105 & 14 & 118 & 436 & 113 & 18 & 134 & 462 & 109 & 29 & 127 & 492 & 113 \\
\hline 9 & 8 & 97 & 510 & 130 & 12 & 102 & 509 & 98 & 2 & 86 & 498 & 106 & 5 & 98 & 513 & 101 & 15 & 94 & 524 & 99 \\
\hline 10 & 3 & 85 & & 115 & 2 & 84 & & 112 & 0 & 80 & & 98 & 0 & 87 & & 103 & 4 & 79 & & 98 \\
\hline 11 & 0 & 77 & & 92 & 0 & 82 & & 91 & 0 & 73 & & 88 & 0 & 87 & & 89 & 0 & 72 & & 82 \\
\hline 12 & 0 & 68 & & 83 & 0 & 72 & & 72 & 0 & 71 & & 76 & 0 & 75 & & 80 & 0 & 70 & & 85 \\
\hline 13 & 0 & 70 & 579 & 62 & 0 & 69 & 545 & 54 & 0 & 72 & 578 & $55 \|$ & 0 & 79 & 592 & 57 & 0 & 73 & 560 & 66 \\
\hline
\end{tabular}

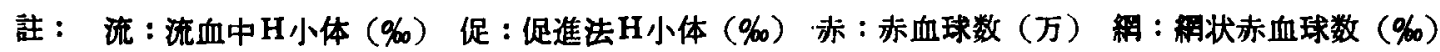


小体のなかつた赤血球の約 $28 \%$ H小体が形成された と云える. 促進法に於ては第1日目殆どすへてて赤血 球にH小体が形成されるがフェニールヒドラジン注射 の場合より崩堎が少い様である。これは促進法に使用 する試薬と注射蒋が $5 \%$ 塩酸ヒドロキシラミン注射の 帮験では同種類であり， $5 \%$ フェニールヒドラジン洗 射の実験では異るから後者の場合はその相乗作用の結 果崩壊が多くなることも考えられる。而して流血中に 於て 1 個の赤血球に数個の小体が個々に明瞭に見られ たが，促進法に於てはこれが融合した様な状態のもの と新たに形成された赤血球に小体 1 個のみのものと 2 種類が認められる．第13日目には略々正常值となるが 网状赤血球は第 7 日乃至第10日目に最高となり以後湖 减の倾向示すが第13日目には少相当高値である。

以上種々の量のフェニールヒドラジン及び参考とし て塩酸ヒドロキシラミンの注射による6.乃至 11. の実 験を行つたが流血中H小体の出現率は前者の方が低く 且つH小体は周囲がぼやけており，H小体含有赤血球 自体がはは立つた様に見え污ない，之に反し塩酸ヒド ロキシラミンの注射ではH小体及び赤血球が比較的明 瞭である. 促進法H小体に於ては赤血球外に遊離した と思われるものがフェニールヒドラジン注射の場合の

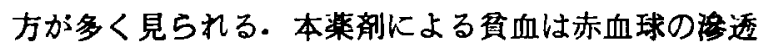
的機械的脆弱性 3 によるものであり，メトへモクロビ ンを形成するが,フェニールヒドラジン，塩酸ヒドロ

キシラミンは夫々赤血球に対する作用の仕方に若干の 相连がある様に考えられる.次に 1 個の赤血球内に出 来たH小体の数が多い程赤血球内容物の見られない赤 血球陰影という状態になつていることは $\mathrm{H}$ 小体が赤血 球内容物と関係を有しているものと思われる。

\section{2. 四坦化㞸莱体重毎 $\mathrm{kg} 0.5 \mathrm{ec}$ 注射}

四塩化岩素を体重毎 $\mathrm{kg} 0.5 \mathrm{cc}$ 筋肉内泩射すると 表14に示す様に流血中H小体は24時間後赤血球边椂に 微細な顆粒として訆められ，第 2 日乃至 3 日目に最も 多いが边緑から離れて中心部へ向う状態は第 3 日目僅 加見られるに過ぎない。而して流血中H小体は第 4 日乃至 5 日目迄認めら机其の後は出現しない。之に反 乙促進法に於ては梗めて特有な推移を辿り第 1 日目よ り中等度に增加し，第 2 日を山として其の後は稍々減 少し第 5 日目頃より再び再び增加し，最高の山を画き 第 6 日乃至 8 日頃より減少し始める。赤血球は第 1 日 目より平均値が增加し始めるが第 1 日目は注射前の平 均値と有意差がない。而して第 3 日最高となり，第 5 日目には平均値が注射前平均値と有意義がなくなる。 網状赤血球は軽度に增加する。

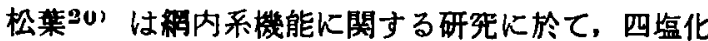
炭素の投与時, Kongorot 指数及ひ徳光法 ${ }^{21}$ 儿於て ，第3日目に Kongorot 指数の增加及び徳光法の時 間延長を認めていると共に，血清高田反応の強陽性を

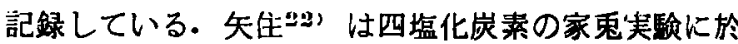

表 14 四塩化炭菜Pro kg $0.5 \mathrm{cc}$ 注射

\begin{tabular}{|c|c|c|c|c|c|c|c|c|c|c|c|c|c|c|c|c|c|c|c|c|}
\hline 症 例 & & & $\begin{array}{l}q \\
3000 \\
300\end{array}$ & & 第 & & $\begin{array}{l}9 \\
2500 \\
\end{array}$ & & & & $\begin{array}{c}\delta \\
2250\end{array}$ & & 第 & & $\begin{array}{c}\delta \\
2320\end{array}$ & & 第 5 & & 2400 & \\
\hline 病 确亘項目 & 流 & 促 & 赤 & 綱 & 流 & 促 & 赤 & 絴 & 流 & 促 & 赤 & 網 & 流 & 促 & 赤 & 稆 & 流 & 促 & 赤 & \\
\hline 前 & 0 & 64 & 530 & 33 & 0 & 65 & 560 & 26 & 0 & 76 & 573 & 23 & 0 & 70 & 582 & 20 & 0 & 67 & 526 & \\
\hline 1 & 4 & 148 & 572 & 32 & 2 & 129 & 581 & 29 & 3 & 136 & 594 & 30 & 5 & 131 & 600 & 27 & 3 & 106 & 551 & \\
\hline 2 & 12 & 156 & 603 & & 14 & 143 & 627 & 33 & 8 & 163 & 634 & 29 & 11 & 145 & 625 & & 8 & 132 & 595 & \\
\hline 3 & 14 & 142 & 614 & & 9 & 133 & 632 & 32 & 9 & 162 & 641 & 31 & 16 & 126 & 639 & & 12 & 108 & 631 & \\
\hline 4 & 6 & 126 & 616 & 38 & 3 & 115 & 604 & 37 & 4 & 144 & 621 & 33 & 7 & 115 & 613 & 39 & 7 & 98 & 624 & 30 \\
\hline 5 & 2 & 136 & 579 & 41 & 0 & 152 & 581 & 39 & 0 & 182 & 572 & 40 & 4 & 137 & 589 & 44 & 2 & 129 & 593 & 38 \\
\hline 6 & 0 & 198 & 521 & 55 & 0 & 168 & 564 & 43 & 0 & 239 & 533 & 44 & 0 & 171 & 576 & 48 & 0 & 163 & 545 & 52 \\
\hline 7 & 0 & 187 & 514 & 43 & 0 & 179 & 521 & 40 & 0 & 212 & 510 & 39 & 0 & 221 & 545 & 42 & 0 & 152 & 520 & 41 \\
\hline 8 & 0 & 182 & 527 & 40 & 0 & 201 & 546 & 36 & 0 & 194 & 523 & 33 & 0 & 173 & 566 & 37 & 0 & 189 & 541 & 35 \\
\hline 9 & 0 & 184 & & & 0 & 173 & & & 0 & 186 & & & 0 & 122 & & & 0 & 170 & & \\
\hline 10 & 0 & 163 & & & 0 & 154 & & & 0 & 160 & & & 0 & 155 & & & 0 & 147 & & \\
\hline 11 & 0 & 121 & & & 0 & 137 & & & 0 & 120 & & & 0 & 113 & & & 0 & 106 & & \\
\hline 12 & 0 & 93 & & 30 & 0 & 104 & & & 0 & 97 & & & 0 & 89 & & & 0 & 80 & & \\
\hline 13 & 0 & 96 & 536 & & 0 & 99 & 542 & 27 & 0 & 95 & 560 & 33 & 0 & 89 & 571 & 25 & 0 & 83 & 539 & 29 \\
\hline
\end{tabular}

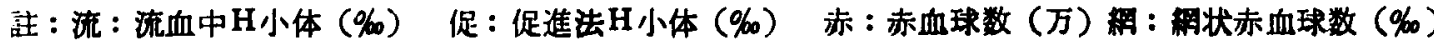


て体重每 $\mathrm{kg} 0.5 \mathrm{cc}$ の过射で 3 日後著明な肝機能 障 碍老起すといい，渡辺 ${ }^{28}$ によれば，24時間後より范 復機転が始まり，1乃至 2 週間で壊死は消失し，4 週 間で完全に修復されると云つている。原 ${ }^{24}$ は 48 乃 至 72 時間で肝障碍最高となり, その後修復機 転に 移り。10乃至 15日で略々正常になると述へている. 著者は Glutamc oxalacetic Transaminase (GOT), Glutamic pyrvic Transaminase (GPT) の测定26)を行い図 1 の如く，GOTで第3日目，G PTは第 4 日目に最高値を示した. 従つて四塩化炭素

図 1

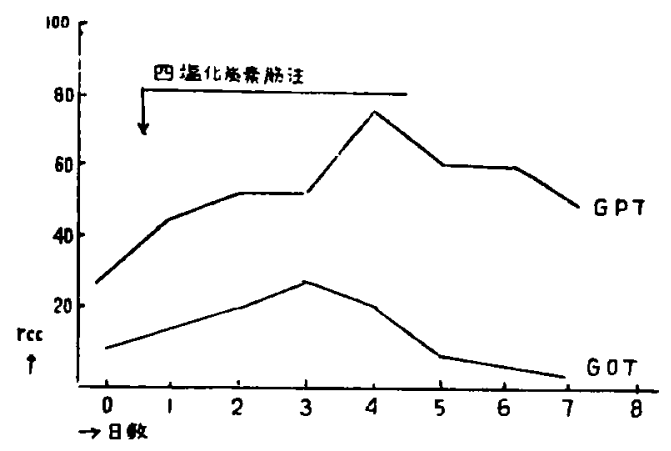

負荷による肝障碍の極期は第 3 日乃至 4 日目と見てよ い。而して流血中にH小体の見られるのは初期であ り.この時期の Kongorot 指数の增加冲色索排泄障
码が強く影郎することが考えら扎るが、德光法の時間 延長等上り見て棢内系機能減退も想像される所であ り，四塩化炭素によつても出現した流血中H小体は泩 射の初期のみであり第 2 日乃至 3 日目が最高となるの であるが，この封期は肝障碍が最高となる時期であ り, 又赫血球が增加しており網内系機能も減退する と想像される時期である。赤血球增加は薬品中毒によ る酸素量の低下、アチドージス，血液の浱縮等考えら れるが、朱, 三浦 ${ }^{26}$ 等はアチドージスの為であると している. 促進法 $\mathrm{H}$ 小体が第11日乃至12日目頃まで中 等度の增加が続くことと合せ考える時, 流血中H小体 の出現が促進法 $\mathrm{H}$ 小体の出現とその出現機転が異るも のであることを示している.

\section{10\%量汁体重毎kg 5ec宛 5 日間道繶注射}

10\%墨计体重每 kg 5ccを耳静脈に注入して 5 日に及 ぶ時は表15の通り第 3 日乃至 5 日目加 5 流血中 $\mathrm{H}$ 小体 が出現し，第10日万至13日迄認められる.而してこれら のH小体は赤血球辺緑にあつて小さい。促進法 $\mathrm{H}$ 小体 は边悢上り稍々離れて存在し，健康家鬼に於けるもの と形態的に差はなく，注射後第 1 日目より增加し，第 2 日乃至 3 日目を頂点とする軽度の傾斜を示しながら第 7 日目に至り，以後渐减した.即与墨计注射を施行して いる間だけ促進法 $\mathrm{H}$ 小体が增加したと言い得る。而も 松柋201, 山形27)等による墨计注射によつて肝機能に

表 $1510 \%$ 墨计 Pro kg $5 \mathrm{cc} 5$ 日間注入

\begin{tabular}{|c|c|c|c|c|c|c|c|c|c|c|}
\hline 定 例 & 第 1 例 & $\begin{array}{l}\stackrel{0}{0} \\
2900 \mathrm{~g}\end{array}$ & 第 2 例 & $\left(\begin{array}{l}\hat{b} \\
2850 \mathrm{~g}\end{array}\right)$ & 第 3 例 & $2500 \mathrm{~g}$ & 第 4 例 & $\left(\begin{array}{ll}9 \\
2400 \mathrm{~g}\end{array}\right.$ & 第 5 例 & $\left(\begin{array}{l}q \\
2500 \mathrm{~g}\end{array}\right)$ \\
\hline 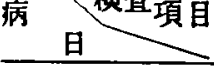 & 流 & 促 & 流 & 促 & 流 & 促 & 流 & 促 & 流 & 促 \\
\hline 前 & 0 & 63 & 0 & 57 & 0 & 69 & 0 & 68 & 0 & 70 \\
\hline 1 & 0 & 203 & 0 & 183 & 0 & 194 & 0 & 213 & 0 & 244 \\
\hline 2 & 0 & 213 & 0 & 200 & 0 & 183 & 0 & 294 & 0 & 250 \\
\hline 3 & 3 & 254 & 0 & 231 & 0 & 209 & 0 & 310 & 0 & 213 \\
\hline 4 & 4 & 243 & 2 & 205 & 4 & 197 & 0 & 298 & 0 & 194 \\
\hline 5 & 8 & 224 & 5 & 198 & 8 & 193 & 5 & 230 & 2 & 170 \\
\hline 6 & 7 & 207 & 7 & 176 & 6 & 175 & 7 & 165 & 3 & 170 \\
\hline 7 & 7 & 193 & 6 & 179 & 7 & 183 & 6 & 149 & 4 & 154 \\
\hline 8 & 5 & 142 & 8 & 132 & 8 & 163 & 5 & 119 & 7 & 143 \\
\hline 9 & 5 & 107 & 4 & 110 & 6 & 92 & 4 & 131 & 6 & 90 \\
\hline 10 & 4 & 98 & 3 & 97 & 4 & 81 & 4 & 86 & 4 & 72 \\
\hline 11 & 0 & 90 & 2 & 83 & 5 & 75 & 3 & 92 & 2 & 77 \\
\hline 12 & 0 & 73 & 0 & 70 & 0 & 74 & 2 & 83 & 1 & 82 \\
\hline 13 & 0 & 71 & 0 & 65 & 0 & 68 & 2 & 75 & 0 & 80 \\
\hline 14 & 0 & 68 & 0 & 68 & 0 & 72 & 0 & 70 & 0 & 75 \\
\hline
\end{tabular}

部：流：流血中H小体(\%) 促：促進法H小体(\%) 
殆ど影暗を認められないので促進法H小体の增加は墨

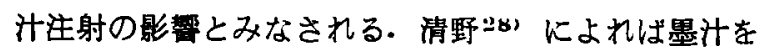
生入した家鬼を飼育する時, 絧内絊胞愪喰した炭粉 をリンバ液を経て間質中に移行させ，この部に於て結 締織に囲まれれる.この自家清掃作用によつて異物を 排除した細胞は再び貪喰作用を恢復し，その機能を発 揮するという. 而して10日以上を経過す机ば星芒細胞 内に於ける炭粉望は城少し, 炭粉含有しない細胞も 少くないという. 流血中H小体の消失はこの網内系機 能の恢復を示していると考えら机促進法H小体の增加 より流血中 $\mathrm{H}$ 小体の出現が遅れることは, 流血中 $\mathrm{H}$ 小 体に絹内系の関与が大きいことを示している。

\section{䊅論}

家束について脱血, フェニールヒドラジン, 塩酸ヒ ドロキシラミン，四塩化炭素，墨计等を負荷し，夫々 流血中 $\mathrm{H}$ 小体数及び促進法 $\mathrm{H}$ 小体数測定, 比較検討 し次の如き結果䒚得た.

1. 健康家鬼に於て流血中H小体は証めら机ない。 促進法 $\mathrm{H}$ 小体の平均値は $66.7 \%$ であつた.

2. 少量又は中等量 1 回脱血及び中等量連続脱血で 流血中 $\mathrm{H}$ 小体は認められなかつた. 大量 1 回脱血に於 ては流血中 $\mathrm{H}$ 小体の少数を認めた. 促進法 $\mathrm{H}$ 小体は赤 血球数に逆比例して出現寸るが流血中H小体とは関係 が認められない。

3.フェニールヒドラジンを注射すると流血中H小 体は注射量に応じ種々の形で現わ机るか，促進法に 於ては流血中に出現したH小体含有赤血球は大半崩壊
し，新たに試験管内で形成されるものが多い。

4. 塩酸ヒドロキシラミンの过射では, 流血中に現 われるH小体はフェニールヒドラジンによるそれよ りも明暸であり，赤血球自体も美麗である. 促進法に 於ても流血中H小体含有赤血球の崩壊がフェニールヒ ドラジン注射時よりも少い。

5. 四塩化炭素負荷した家鬼では初期に流血中H 小体か僅かに認められるが小さい：促進法 $\mathrm{H}$ 小体は第 10日乃至12日目迄中等度に增加する.

6. 墨汁注射に於ては流血中 $\mathrm{H}$ 小体は注射開始後第 2 日乃至 4 日目に出現し，促進法H小体は注射してい る期間に增加し，中止と其に減少する. 流血中H小体 は網内系機能が関係し, 促進法H小体は墨计注射自体 の影筫が大きいと思われる。

以上よりして、流血中H小体と促進法H小体とは本 熊㓯にし,促進法H小体がたとえ生体内に於てH小体 の準備状熊として存在するとしても，それが直ちに生 体内に於てH小体となるものではないと考えられる。

本論文の要旨は第11回及ひ第13回日本内科学会中国 四国地方会に於て発表した。

本研究にあたり終始御娊篤なる御指導を戴いた岡山 大学小坂教授, 国立岩国病院岩原副院長に感謝する. 尙本研究の機会を与艺られた国立岩国病院渡辺院長に 感謝する。

又本研究には厚生省治療研究費の補助を得た. 附記 して謝意を表する。

\section{主 要 文 献}

1）河村：京都府医大誌，47，315, 昭25.

2) 金井：臨床検査法提要，VI-4，昭30.

3) W. A. Sodemann : Pathologic Physiol. 2nd ed., 1956.

4) 安東・田岶：動物実䮖法, 132, 昭30.

5) 林: 日本人並びに日本廉医学実臥動物の解剖学及 び生理学計数, "昭31，201，210.

6 ) 中山：日血会誌, 18，358，昭30.

7) R. Heinz : Handbuch d. exper. Patholog. u. Pharmak. Vol. 1, 336, 1904.

$8)$ M. Kiese \& L. Seipelt : Arch. f. exper. Path. u. Pharmakol., 200, 648, 1943.

9) M. H. Fertman \& C. A. Doan : Blood, 3. 349, 1945.

10) F. Jang : Naturwissenschaften, $30,472,1941$.

11) F. Jang: Klinische Wschr., 22. 42, 1943.
1941.

12) S. H. Webster \& E. J. Liljegren : J. Phamacol. and Exper. Therap., 95, 201, 1949.

13) S. H. Webster : Blood, 4, 479. 1949.

14) W. O. Cruz : Am. J. M. Sc., 202, 81, 1941.

15) R. Heinz : Virch. Arch. f. path. Anat., 168. $485,1902$.

16) L. Hess \& H. Müller : Wien Klin. Wschr., 26. 1831, 1913.

17) V. Schilling : Deutsche Med. Wschr., 47. $825,1921$.

18) I. Zadek \& K. Burg : Folia haemat.,41. 333, 1930.

19) N. G. Markoff : Schweiz. med. Wschr., 73. 656. 1943. 
20）松集：医学研究，23，264, 昭28.

21）德光・鄷田：日病会誌, 21,264 , 昭 6 .

22）矢住：熊医会誌，27，40，昭28.

23）渡辺・山田：総合研究報告集録医学及ひ菓物編, 480 , 昭30.

24）原：日内会誌, 44, 49, 昭30.
25）浅野：日臨病理会中四地方会, 昭33.

26）朱, 三浦：熊医会誌, 30，435, 昭31.

27) 山形: 臨床内小科, 3, 11, 昭23.

28）清野：生体染色研究の現況及びその検 査術 式, 210 , 大 10 .

\title{
Studies on Heinz Bodies \\ Part 2. Relationship between Heinz Bodies in the Circulating Peripheral Blood of the Rabbit and Heinz Bodies be the in vitro Accelerating Method
}

\author{
By \\ Sadaaki MATSUURA \\ Department of Internal Medicine Okayama University Medical School \\ (Director : Prof. Kiyowo Kosaa and Dr. Sadanari Yuwahara of Iwakuni \\ National Hospital)
}

After giving blood depletion, phenylhydrazine, hydrochloric acid hydroxylamine, carbon tetrachloride, and carbon black to rabbits the author estimated the number of Heinz bodies in the circulating blood of each animal and the number of Heinz bodies appearing in the in vitro accelerating test, and studied the relationship between the two appearances.

1. In the circulating blood of normal rabbits no Heinz body can be recognized. By the in vitro accelerating method erythrocytes containing Heinz bodies amount ot 66.7 per cent.

2. In the circulating blood of the rabbits depleted of blood once in a small or a large amount, or successively depleted of blood in an intermediate amount no Heinz body can be found. the circulating blood of the rabbits depleted of its blood once in a large amount a few Heinz bodies can be detected. By the in vitro method Heinz bodies appear in an inverse proportion to the number of erythrocytes, but there seems to be no relation with the number of Heinz bodies in the circulating blood.

3. When phenylhydrazine is injected, Heinz bodies appear in the circulating blood in various forms according to the dose of the injection. However, by the in vitro method the greater majority of Heinz bodies appeared in the circulating blood are destroyed, and many Heinz bodies observable in this instance are the ones produced anew in vitro.

4. In the case injected with hydrochloric acid hydrocylamine, Heinz bodies appearing in the circulating blood are more distinct and erythrocytes themselves are more brilliant than those in the case injected with phenylhydrazine. Even by the in vitro accelerating method Heinz bodies appeared in the circulating biood are destroyed in a lesser number than in the case of the phenylhydrazine injection.

5. In the rabbits administered with carbon tetrachloride Heinz bodies can be recognized in the circualting blood soon after the injection but they are a few in number and small in size. By the in vitro method the blood taken from 10 to 12 days after the injection an 
intermediate number of Heinz bodies are formed.

6. In the case injected repeatedly with carbon black Heinz bodies appear in the circulating blood 2 to 4 days after the initiation of the injection, and by the in vitro accelerating method Heinz bodies increase as long as the injection is kept up, but they decrease in number at the cessation of the injection. It seems that the function of the reticuloendothelial system is responsible for the formation of Heinz bodies in the circulating blood while the carbon black injection itself is greatly responsible for the appearance of Heinz bodies by the in vitro method.

From these, the Heinz body in the circulating blood has the characteristic traits that are different from those of the Heinz body appearing in the in vitro accelerating method. Therefore even the latter is present in vivo in a preparatory state, it is believed that the latter will not immediately be transformed into the in vivo Heinz body. 